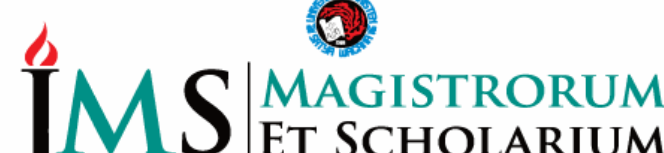

\section{Pendampingan Pembenahan dan Pengelolaan Rumah Dataku dan Informasi Keluarga Kampung Keluarga Berkualitas (KB) Kelurahan Kauman Kidul Salatiga}

\author{
Yeremia Sabatani Ari* \\ Wendy Wijaya T. Gari \\ Muhamad Dwi Mardiyanto \\ Aurelia Jessica \\ Nurayu Wulandari \\ Daru Purnomo \\ Fakultas IImu Sosial dan IImu Komunikasi, Universitas Kristen Satya Wacana
}

\section{A R T I C L E I N F O}

Article history:

Received 22-01-2021

Revised 29-01-2021

Accepted 24-05-2021

Key words:

Pengabdian Masyarakat, Rumah Data Kependudukan dan Informasi Keluarga, Kampung KB

\begin{abstract}
A B S T R A C T
Community service and empowerment are activities that try to provide progress for the welfare of society and educate the life of the nation. In this article community service and empowerment through the Integrated Field Practice (IFP) activities will describe the activities of improving the classification of the Population Data and Family Information Houses, assisting data input and making data variable formats as well as making social media accounts and video profiles of Kampung KB Teratai. Based on the results of field practice that was carried out, this improvement and assistance provided benefits for administrators of Rumah Data and Kampung $K B$ where the administrators got a deeper understanding of digital data input, supported by the completeness of existing data formats, availability of places to verify, analyse. and data archiving and the existence of media to promote tourism activities and potential in Kauman Kidul.
\end{abstract}

\section{A B S T R A K}

Pengabdian dan pemberdayaan masyarakat merupakan kegiatan yang berusaha memberikan kemajuan bagi kesejahteraan masyarakat dan mencerdaskan kehidupan bangsa. Dalam artikel ini pengabdian dan pemberdayaan masyarakat melalui kegiatan Praktek Lapangan Terpadu (PLT) akan memaparkan kegiatan pembenahan klasifikasi Rumah Data Kependudukan dan Informasi Keluarga, pendamping inputting data dan pembuatan format variabel data serta pembuatan akun sosial media dan video profil Kampung KB Teratai. Berdasarkan hasil praktek lapangan yang dilakukan, pembenahan dan pendampingan ini memberikan manfaat bagi pengurus Rumah Data dan Kampung KB dimana para pengurus mendapatkan pemahaman yang lebih dalam akan

\footnotetext{
*Corresponding author: 372017002@student.uksw.edu
} 
inputting data secara digital dengan didukung oleh kelengkapan format data yang ada, tersedianya tempat untuk melakukan verifikasi, analisis dan pengarsipan data serta adanya media promosi kegiatan dan potensi wisata yang ada di Kauman Kidul.

\section{PENDAHULUAN}

Undang-undang Nomer 52 tahun 2009 (LN. 2009/ No. 161, TLN NO. 5080, LL SETNEG : 36 HLM) tentang Perkembnagan Kependudukan dan Pembangunan Keluarga sebagai dasara pelaksanaan Program Kependudukan dan Keluarga Berencana Nasional, secara tegas mengatur bahwa pembangunan kependudukan tidak hanya mengatur bidang Keluarga Berencana (KB) saja, tetapi juga berkaitan dengan masalah pengendalian Kependudukan dan Pembangunan Keluarga atau juga dikenal dengan istilah Kependuduk, Keluarga Berencana, dan Pembangunan Keluarga (KKBPK) ( https://referensi.elsam.or.id/2014/10/uu-nomor-52-tahun-2009-tentangperkembangan-kependudukan-dan-pembangunan-keluarga/). Menurut Purnomo (2021) secara politis pemerintah ingin memeperkuat kembali peran pembangunan kependudukan di era otonomi daerah, karena aspek pengendalian kependudukan cenderung terabaikan pasca reformasi. Hal ini terbukti di Sensus Penduduk (SP) 2010 Indonesia mengalami kegagalan dalam mengerem laju pertumbuhan penduduknya. Pada SP 2000 angka pertumbuhan penduduk telah mampu menekan hingga 1.45\%, sedangkan data SP 2010 anka pertumbuhan penduduk justru mengalami pengikatan menjadi $1.49 \%$, dan akibatnya Indonesia akan mengalami pertambahan penduduk (bayi) setiap tahunnya antara $4.5-4.9$ Juta bayi. (BPS, 2011)

Untuk mewujudkan program KKBPK dan agenda prioritas pembangunan (NAWACITA), yakni agaenda nomor 3 (membangun Indonesia dari pinggiran), dan agenda nomor 5 (meningkatkan kualitas hidup manusia Indonesia" melalui "Pembangunan Kependudukan dan Keluarga Berencana" dengan fokus penggarapan pada Dimensi Pembangunan Kesehatan serta Mental/Karakter (Revolusi Mental); maka dibentuklah Kampung Keluarga Berkualitas (KB) pada setiap satuan wilayah setingkat Kecamatan di Seluruh Indonesia. (BKKBN, 2017).

Kampung Keluarga Berkualitas (KB) Teratai Kelurahan Kauman Kidul telah didirikan sejak tahun 2017 dan telah menjadi satu-satunya Kampung KB percontohan se-Salatiga dan salah satu Kampung KB yang telah dinaikkan statusnya menjadi setingkat dengan kelurahan. Dengan status Kampung KB percontohan maka sudah sewajarnya Kampung KB Teratai Kauman Kidul memenuhi persyaratan menjadi Kampung KB percontohan, namun sayangnya aspek keberadaan Rumah Data Kependudukan dan Informasi Keluarga yang merupakan variabel penting dari sebelas variabel untuk menjadi Kampung KB percontohan tidak ada dan sementara dialihkan ke rumah warga. Hal ini menjadi masalah dalam pengembangan Kampung KB Teratai Kauman Kidul untuk menjadi Kampung KB yang paripurna ke depannya.

Rumah Data Kependudukan dan Informasi Keluarga sendiri adalah kegiatan kelompok kegiatan (Poktan) masyarakat yang melaksanakan kegiatan pengumpulan, verifikasi, analisis, penyajian serta pemanfaatan data kependudukan dan keluarga serta pembangunan di tingkat desa/kelurahan. Tujuan Rumah Data Kependudukan dan Informasi Keluarga ini tidak lain untuk membangun kepedulian dan kesadaran akan 
data serta membangun kelompok kegiatan dalam bidang data yang menjadi mitra strategis pemerintahan dalam membuat dan mengambil sebuah kebijakan. Oleh sebab itu, Kampung KB dalam mempunyai Rumah Data Kependudukan dan Informasi Keluarga bukan semata hanya sebagai syarat menjadi Kampung KB percontohan namun menjadi hal yang wajib dimiliki oleh setiap Kampung KB guna menjadi salah satu instrumen dalam meningkatkan kesejahteraan masyarakat. Keberlangsungan Rumah Data Kependudukan dan Informasi Keluarga itu sendiri ditentukan pada pemenuhan data dari Rumah Data Kependudukan dan Informasi Keluarga, yang setidaknya ada 7 variabel data penting yang harus dimiliki oleh setiap Rumah Data berdasarkan pemaparan materi oleh BKKBN pada kegiatan lokakarya mini di Kelurahan Kauman Kidul (BKKBN, 2020). Selain itu, penguasaan cara inputting data dengan menggunakan Microsoft Office Word dan Excel sangat perlu untuk dikuasai. Pada kasus Rumah Dataku Kauman Kidul, format variabel data belum semua dimiliki dan cara inputting data masih dilakukan secara manual sehingga hal ini menjadi fokus lain dalam program pengabdian masyarakat di Kauman Kidul.

Selain permasalahan Rumah Data Kependudukan dan Informasi Keluarga, dalam meningkatkan kesejahteraan masyarakat di Kampung KB Kelurahan Kauman Kidul, maka aspek pengembangan potensi alam yang dimiliki perlu dikembangkan dan dipromosikan. Salah satu kondisi alam yang dimiliki dan perlu dikembangkan oleh Kelurahan Kauman Kidul adalah Kampung Wisata Sitalang. Kampung wisata ini merupakan bentuk lintas program yang dimiliki oleh kelurahan untuk meningkatkan kesejahteraan masyarakat. Adapun usaha yang dilakukan dalam meningkatkan kesejahteraan tersebut belum dilakukan secara maksimal sehingga promosi melalui media sosial sangat perlu untuk dilakukan.

Dengan berbagai kendala dan permasalahan yang ada di Kampung KB Kauman Kidul, maka pengabdian dan pemberdayaan masyarakat dilakukan beberapa program utama yang diharapkan dapat memberikan kontribusi terhadap masyarakat di Kampung KB Teratai. Adapun program tersebut diantaranya: (1) Penggarapan Rumah Data Kependudukan dan Informasi Keluarga dan Pojok Baca; (2) Penggarapan Format Berbagai Variabel Data; (3) Pendampingan Inputting Data; dan (4) Pembuatan Media Sosial dan Video Profil Kampung KB Teratai. Adapun melalui keempat program pengabdian masyarakat ini, tujuan yang ingin dicapai adalah terbangunnya sarana fisik dan non-fisik bagi pengurus Rumah Data dan Kampung KB melalui ketersediaan Rumah Dataku dan Format Data sehingga memudahkan pengurus dalam melakukan inputting dan mengarsipkan data-data. Selain itu pula tersedianya media promosi kegiatan Kampung KB Teratai melalui kepemilikan akun media sosial (Instagram) dan video profil Kampung KB Teratai.

\section{METODE PELAKSANAAN}

Dalam pelaksanaan proses pengabdian masyarakat ini, ada beberapa metode yang digunakan dalam pelaksanaan eksekusi program pengabdian, antara lain: 1) melakukan need assessment, 2) menetapkan program utama dan pendukung, 3) penetapan rencana-rencana, langkah-langkah strategis dan eksekusi program.

Tahapan awal dalam pelaksanaan pengabdian masyarakat yakni mencoba untuk melakukan need assessment dalam rangka menggali peluang dan tantangan terkait 
tujuan utama yaitu mewujudkan Kampung KB Teratai Kelurahan Kauman Kidul pada tingkat klasifikasi Kampung KB Paripurna. Teknik wawancara dan observasi dilakukan terhadap beberapa tokoh Pokja dan kelurahan serta mengobservasi beberapa objek program. Dalam mewujudkan hal tersebut langkah awal yang dikerjakan adalah menggali informasi dan indikator- indikator yang digunakan untuk mengklasifikasikan tingkat kemandirian Kampung KB. Setelah memahami indikator-indikator yang digunakan dalam pengklasifikasian Kampung $\mathrm{KB}$, hal selanjutnya adalah memfokuskan diri pada program pemberdayaan pada indikator rumah data. Hal ini bertujuan untuk membuka kerjasama dengan pihak kelurahan guna terwujudnya kemandirian data Kampung KB Teratai Kelurahan Kauman Kidul dengan harapan data yang berasal dari Rumah Dataku yang didapatkan dari swadaya masyarakat ini dapat menjadi rujukan dalam proses perencanaan pembangunan bagi kelurahan sendiri. Selain itu proses need assessment ini juga bertujuan untuk menggali informasi terkait kelengkapan data yang sudah ada dan kemudian kami sesuaikan dengan indikator klasifikasi Kampung KB Paripurna. Proses need assessment dilakukan pada minggu pertama kegiatan pengabdian. Proses dengar pendapat antara tim pengabdian dan pokja (Kelompok Kerja) Kampung KB Teratai terkait masalah dan hambatan dalam proses pengumpulan dan pengelan data terjadi pada minggu pertama ini.

Setelah proses need assessment selesai, dibuat komparasi setiap aspirasi yang didapatkan selama proses need assessment dengan mewujudkannya berupa satu program utama dan 2 program pendukung. Perwujudan bangunan kantor sekretariat Rumah Data Kependudukan dan Informasi Keluarga, sarana pengolahan data dan dasar hukum (SK) menjadi program utama kami. Sedangkan pembuatan video profil dan sosial media berupa akun Instagram dijadikan sebagai program pendukung. Walaupun demikian, program utama dan pendukung tidak dapat dipisahkan satu dengan yang lain karena merupakan satuan kesatuan program. Pemisahan program utama dan pendukung ini hanya digunakan sebagai strategi pembagian waktu eksekusi program. Setelah merencanakan beberapa program, hal yang selanjutnya yang dibuat adalah membuat langkah-langkah strategis untuk mengeksekusi program. Langkahlangkah strategis ini digunakan sebagai panduan kerja mingguan. Setelah menetapkan langkah-langkah strategis barulah eksekusi program dimulai. Pada tahapan pertama, eksekusi bangunan kesekretariatan Rumah Data Kependudukan dan Informasi Keluarga dengan mengajukan permohonan kepada pihak kelurahan untuk memfasilitasi fisik kantor sekretariat.

Setelah itu, membuat desain ruangan yang akan digunakan sebagai Rumah Data Kependudukan dan Informasi Keluarga serta kolaborasi dengan pojok baca yang dimiliki oleh kelurahan. Setelah fisik kantor sekretariat rumah data terwujud, pekerjaan dilanjutkan dengan pembuatan format data Excel dan pengajuan dasar hukum atau SK kepengurusan rumah data ke pihak Kecamatan. Karena terdapat risiko yang tinggi akibat kondisi pandemi Covid-19 maka metode pengumpulan dan pengarsipan data yang biasa dilakukan oleh ibu-ibu kader pokja Rumah data dialihkan dengan membuatkan format data berupa kolom-kolom Excel yang didesain sedemikian rupa dengan menggunakan rumus-rumus. Pembuatan format data Excel yang bertujuan untuk mempermudah pekerjaan ibu-ibu kader dalam mengumpulkan data serta pengarsipan data dengan cara digitalisasi data dalam format Excel. Sembari mempersiapkan format Excel, kami juga mengerjakan program pendukung untuk 
memangkas waktu yang lama. Dalam proses kegiatan, kelompok kami bagi menjadi 2 tim agar lebih efektif dalam bekerja. Setelah semua program yang berkaitan dengan kantor sekretariat rumah data dan format data selesai, kami melakukan pendampingan dengan menyosialisasikan format data yang telah kami buat dan memberikan tutorial dalam proses pengolahan data. Dengan adanya pendampingan dan pelatihan ini diharapkan dapat memberikan kemudahan bagi pokja Rumah Data Kependudukan dan Informasi Keluarga menyiapkan data-data kependudukan bagi pembangunan wilayah kelurahan. Adapun langkah strategis mingguan yang dilakukan dalam kegiatan pengabdian masyarakat ini ditunjukkan pada Tabel 1 dan secara garis besar tahapan proses penggarapan program pengabdian masyarakat ditunjukkan pada Gambar 1.

Tabel 1. Langkah-langkah Strategis Penggarapan Program PLT Kauman Kidul

\begin{tabular}{|c|c|}
\hline Minggu & Kegiatan \\
\hline Pertama & Observasi lapangan dan pematangan program \\
\hline Kedua & $\begin{array}{l}\text { Verifikasi indikator rumah data dan serta konsep desain } \\
\text { Rumah Dataku dan Pojok Baca }\end{array}$ \\
\hline Ketiga & $\begin{array}{l}\text { Re-check data Rumah dataku dan pembuatan format } \\
\text { inputting data dan penggarapan rumah data }\end{array}$ \\
\hline Keempat & $\begin{array}{l}\text { Updating data dan penggarapan Rumah Dataku dan Pojok } \\
\text { Baca }\end{array}$ \\
\hline Kelima & $\begin{array}{l}\text { Updating data dan pendampingan pembuatan video profile } \\
\text { dan media sosial }\end{array}$ \\
\hline Keenam & $\begin{array}{l}\text { Pembuatan video profile Kampung KB Teratai Kelurahan } \\
\text { Kauman Kidul }\end{array}$ \\
\hline Ketujuh & Editing video dan pendampingan digitalisasi data \\
\hline Kedelapan & Sharing hasil \\
\hline
\end{tabular}




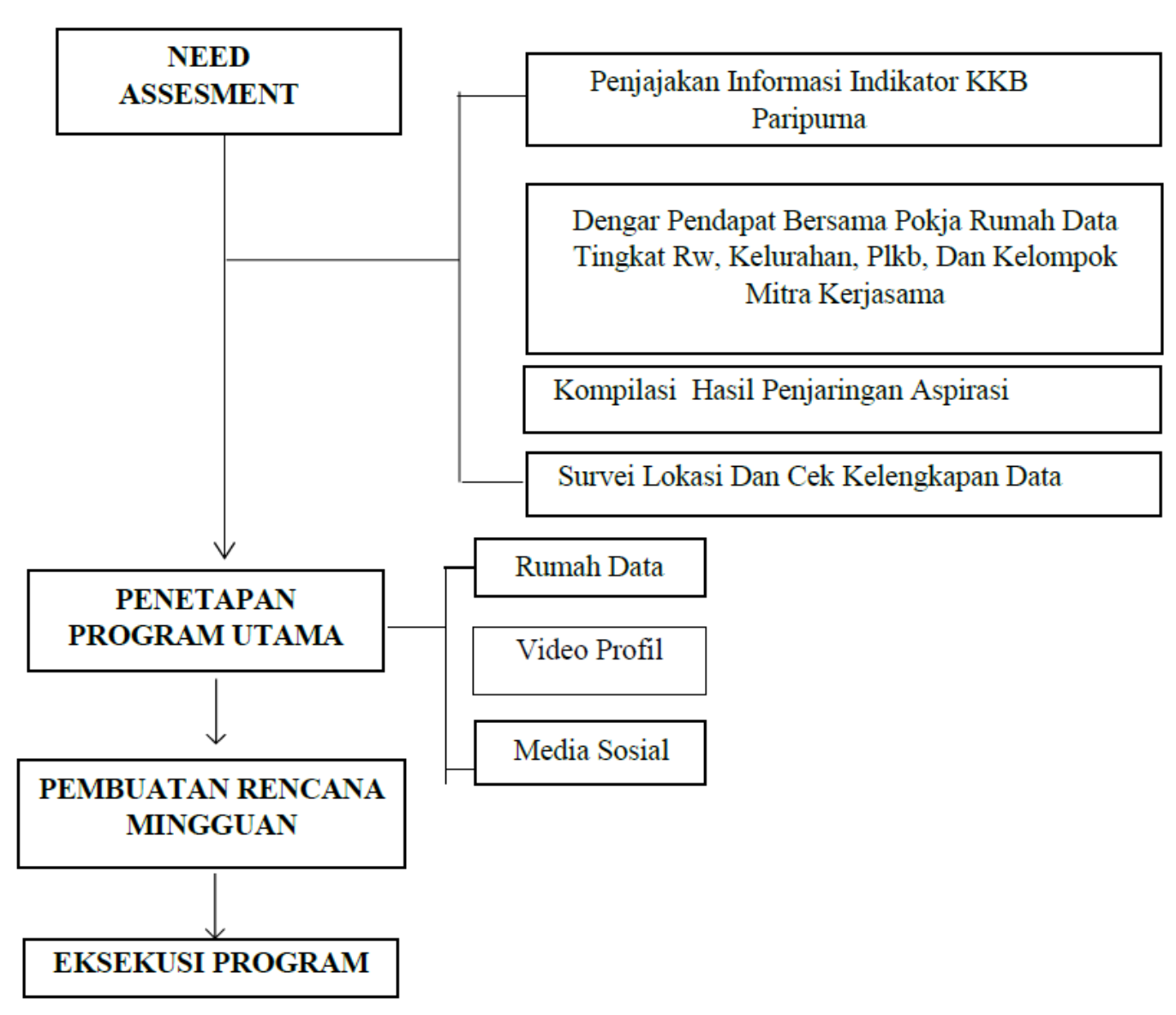

Gambar 1. Tahapan Proses Penggarapan Program PLT Kauman

\section{HASIL DAN PEMBAHASAN}

\section{Penggarapan Rumah Data Kependudukan dan Informasi Keluarga}

Penggarapan Rumah Data Kependudukan dan Informasi Keluarga merupakan salah satu kriteria yang harus dipenuhi oleh setiap Kampung KB. Rumah Data ini sendiri digunakan sebagai bank data masyarakat dimana berbagai macam data dapat dilihat oleh masyarakat maupun digunakan oleh pihak tertentu sebagai acuan dalam mencari informasi dan pengambilan keputusan. Di samping itu dengan data yang ada, permasalahan-permasalahan yang ada di daerah tersebut dapat lebih mudah ditemukan dan dapat dijadikan rekomendasi kepada kelurahan maupun pemerintahan kota untuk dapat mengentaskan dan memprioritaskan masalah yang ada. Dengan kegunaan Rumah Data yang begitu penting, maka keadaan fisik Rumah Data Kependudukan dan Informasi Keluarga sangat penting untuk ada. Selain itu pula, klasifikasi pendirian Rumah Data Kependudukan dan Informasi Keluarga lainnya seperti aspek administratif, sarana prasarana harus dipenuhi pula oleh setiap Kampung KB.

Di Kampung KB Kauman Kidul sendiri, ketersediaan Rumah Data secara fisik maupun administratif tersebut belum terpenuhi sepenuhnya, karena ada beberapa klasifikasi pendirian Rumah Data yang belum terpenuhi. Oleh sebabnya, penggarapan Rumah Data ini selama masa pengabdian masyarakat memakan waktu hampir dua 
bulan untuk memenuhi semua klasifikasi Rumah Data baik secara fisik maupun administratif. Adapun hasil penggarapan tersebut ditunjukkan pada perbandingan Tabel 2.

Tabel 2. Perbandingan Pemenuhan Klasifikasi Rumah Data Kependudukan dan Informasi Keluarga

\begin{tabular}{cccc}
\hline Klasifikasi & Sebelum & Sesudah & Keterangan \\
\hline Rumah Dataku & Belum Ada & Ada & Selesai \\
Dasar Hukum (SK) & Belum Ada & Ada & Selesai \\
Sarana Prasarana & Belum Semua & Lengkap & Selesai \\
Ketersediaan Data & Belum Semua & Belum Semua & On Process \\
Bentuk Penyajian Data & Manual & Digital & On Process
\end{tabular}

\section{Sumber: Materi Lokakarya Mini BKKBN di Kauman Kidul (BKKBN, 2020)}

Dari perbandingan Tabel 2 dapat dilihat bahwasanya klasifikasi pendirian Rumah Data Kependudukan dan Informasi Keluarga sudah hampir tercapai sepenuhnya. Kepemilikan bangunan fisik Rumah Dataku sudah ada yang dimana dari awalnya Rumah Data Kampung KB Teratai Kauman Kidul menumpang di rumah warga (Ibu Utami) tapi sekarang memiliki bangunan fisik yang terletak di Kantor Kelurahan Kauman Kidul. Adapun gambar progres penggarapan Rumah Data Kependudukan dan Informasi Keluarga dapat dilihat pada Gambar 2:

\section{Sebelum:}
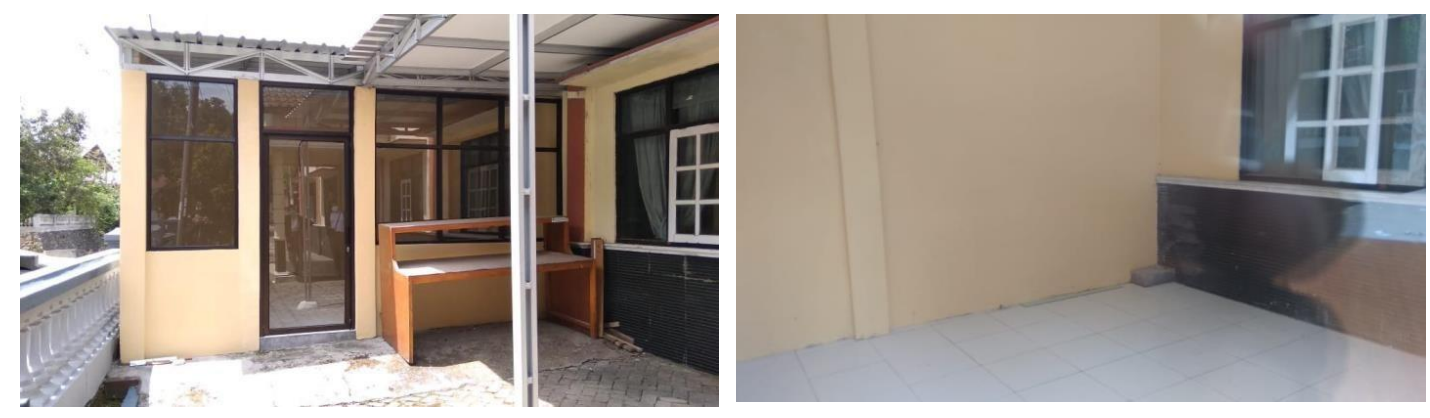

\section{Sesudah:}
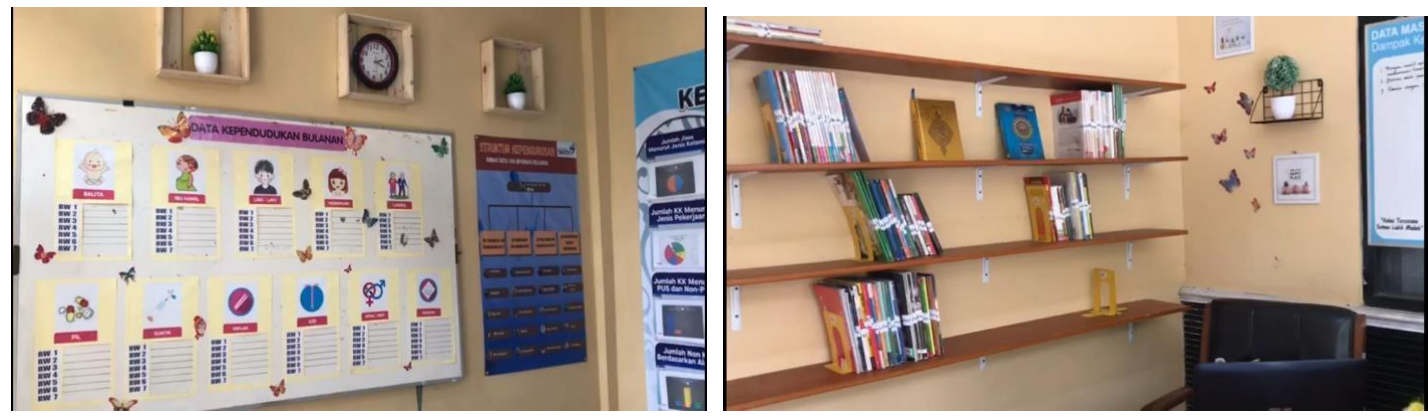

Gambar 2. Progres Penggarapan Rumah Data 
Klasifikasi kedua yakni dasar hukum (SK) berdirinya Rumah Data Kependudukan dan Informasi Keluarga sudah dibuat dan sudah memiliki SK kepengurusan Rumah Data Kependudukan dan Informasi Keluarga. Kepengurusan, ini terdiri dari kader Kampung KB Teratai di tingkatan RW dan dikolaborasikan dengan masyarakat Kauman Kidul lainnya yang terdiri dari 7 RW. Selanjutnya, untuk pemenuhan sarana dan prasarana sudah hampir terpenuhi semuanya. Sedangkan untuk klasifikasi ketersediaan data untuk sementara masih berisi hanya sebagian data yang ada seperti Data KB dan Data Kependudukan. Untuk kelengkapannya sedang dalam proses mengingat pandemi Covid-19 yang semakin marak dan terus tambah angkanya di Kauman Kidul, sehingga menghambat pengambilan data oleh ibu-ibu kader dan pengurus Rumah Dataku. Sedangkan bentuk penyajian data sendiri sudah menuju penyajian data yang berbasis digital seperti apa yang sudah dijelaskan sewaktu pendampingan.

Selain itu pula Rumah Data Kependudukan dan Informasi Keluarga Kauman Kidul dikolaborasikan dengan dibuatnya Pojok Baca yang berada di dalam Rumah Data Kependudukan dan Informasi Keluarga, dimana Pojok Baca ini dapat digunakan oleh warga untuk mencari referensi buku yang diperlukan baik secara elektronik melalui link yang sudah disiapkan ataupun berbentuk hardcopy. Dengan sudah tersedianya Rumah Dataku dan Informasi Keluarga di Kauman Kidul, maka diharapkan Rumah Data ini dapat menjadi ruangan bagi para pengurus Rumah Dataku dalam melakukan verifikasi dan analisis data yang berbasis digital melalui perangkat elektronik seperti komputer yang sudah ada serta dapat menjadi tempat rapat bulanan bagi para pengurus Rumah Dataku dan Kampung KB sebagaimana yang diharapkan oleh ibu-ibu kader yang ada di Kauman Kidul.

\section{Penggarapan Format Data dan Pendampingan Inputting Data Penggarapan Format Data}

Kelengkapan data dalam Rumah Data Kependudukan dan Informasi Keluarga merupakan suatu hal yang penting yang tentunya didukung oleh ketersediaan format yang mumpuni. Pada kegiatan Lokakarya Mini Kampung KB yang diadakan pada 2 Oktober 2020 di Kelurahan Kauman Kidul (Gambar 3), pihak BKKBN dari Semarang menyampaikan materi mengenai Kampung KB dan Rumah Data. Berdasarkan lokakarya tersebut diketahui bahwa di dalam Rumah Data Kependudukan dan Informasi Keluarga ada tujuh variabel data yang terdiri dari 39 indikator data yang harus dimiliki oleh setiap Rumah Data, seperti yang ditunjukkan Tabel 3. 


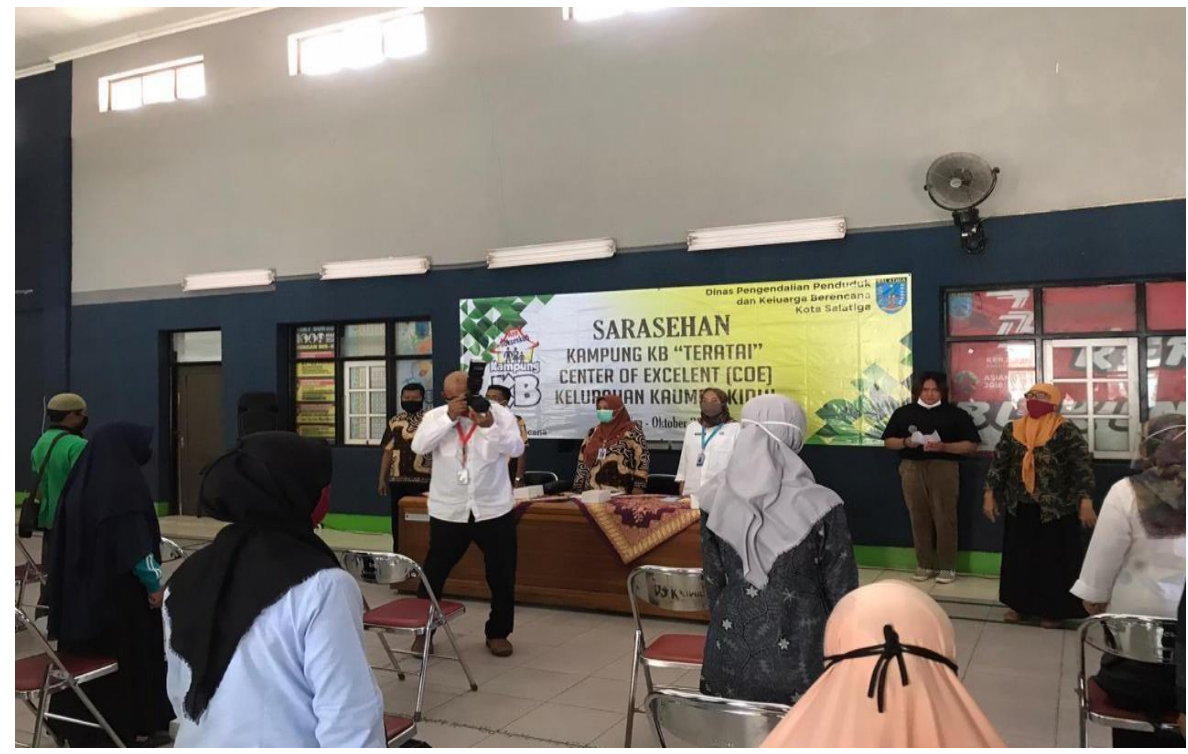

Gambar 3. Kegiatan Loka Karya Mini Kampung KB

Tabel 3. Klasifikasi Variabel dan Indikator Data

\begin{tabular}{ll}
\hline \multicolumn{1}{c}{ Variabel Data } & \multicolumn{1}{c}{ Indikator Data } \\
\hline Data Kuantitas Penduduk & Jumlah dan Komposisi Penduduk Jumlah Keluarga \\
& Jumlah Anak Per-Keluarga Jumlah Pasangan Usia Subur \\
& Jumlah Kesetaraan Ber-KB \\
Data Kualitas Penduduk & Jumlah Anak Sekolah Jumlah Anak Putus Sekolah Jumlah \\
& Anak Stunting \\
Data Mobilitas Penduduk & Jumlah Penduduk yang Masuk Jumlah Penduduk yang Keluar \\
& Jumlah Komuter \\
& Jumlah Penduduk Musiman \\
& Jumlah Tribina (BKB, BKR, BKL dan UPPKS) \\
Data Pembangunan Keluarga & Jumlah Posyandu Jumlah Paud \\
& Jumlah Kelompok Usaha Bersama \\
& \\
& \\
Data Administrasi Kependudukan & Jumlah Nikah, Talak, Cerai, Rujuk (NTCR) \\
& Jumlah Pasangan yang Memiliki Akte Nikah \\
& Jumlah Penduduk yang Memiliki Akte Lahir \\
& Jumlah Penduduk yang Memiliki Kartu Tanda Penduduk (KTP) \\
& Jumlah Keluarga yang Memiliki Kartu Keluarga (KK) \\
& Data Kematian \\
& Jumlah Anak yang Memiliki Kartu Identitas Anak \\
&
\end{tabular}


Data Perlindungan Sosial

Data Potensi Desa
Data Penerima Keluarga Sejahtera (KKS) Data Penerima Kartu Indonesia Sehat (KIS)/ Penerima Bantuan Iuran Jaminan

Kesehatan Nasional (PBI-JKN)

Data Penerima Kartu Indonesia Pintar (KIP)/ Bantuan Siswa

Miskin (BSM)

Data Penerima Program Keluarga Harapan (PKH)

Data Penerima Beras Sejahtera (Rastra)/ Beras Miskin (Raski)

Data Kesertaan BPJS Kesehatan

Data Kesertaan BPJS Ketenagakerjaan

Jumlah Sekolah Jumlah Tempat Ibadah Jumlah Puskesmas

Jumlah Pasar

Jumlah Balai Warga Jumlah Poskamling

Jumlah Rumah yang Tidak Layak Huni

Data Jalan yang Belum Diaspal

Data Bencana dan Korban

\section{Sumber: Materi Lokakarya Mini BKKBN di Kauman Kidul (BKKBN, 2020)}

Pra kondisi data di Kampung KB Teratai sebelum pengabdian masyarakat dilaksanakan, ketersediaan format data hanya ada pada format data kesetaraan ber-KB dan format data PUS dan Non-PUS. Oleh karenanya, klasifikasi ketersediaan data yang ada pada Tabel 3 belum dapat tercapai karena tidak adanya format data yang mendukung ketersediaan data tersebut. Untuk itu kami menyiapkan format data yang sesuai pada Tabel 3, dimana kegiatan penggarapan format data ini dimulai dengan tahap verifikasi format data yang sudah ada di pengurus Kampung KB Teratai, kemudian dilanjutkan dengan konsultasi dan cross check data ke Pendamping Lembaga Keluarga Berkualitas (PLKB) Kauman Kidul. Kemudian setelah melihat format apa saja yang sudah ada di kader sekaligus pembuatan format seperti apa yang perlu dibuat setelah berkonsultasi dengan PLKB, penggarapan format data mulai dilakukan. Ketercapaian format data ini dapat dilihat pada penjelasan Tabel 4:

Tabel 4. Ketercapaian Pembuatan Format

\begin{tabular}{ll}
\hline \multicolumn{1}{c}{ Variabel Data } & \multicolumn{1}{c}{ Keterangan } \\
\hline Data Kuantitas Penduduk & Sudah dibuatkan dan disosialisasikan \\
Data Kualitas Penduduk & Sudah dibuatkan dan disosialisasikan \\
Data Mobilitas Penduduk & Sudah dibuatkan dan disosialisasikan \\
Data Pembangunan Keluarga & Sudah dibuatkan dan disosialisasikan \\
Data Administrasi Kependudukan & Sudah dibuatkan dan disosialisasikan \\
Data Perlindungan Sosial & Belum dibuatkan \\
Data Potensi Desa & Sudah dibuatkan dan disosialisasikan \\
\hline
\end{tabular}

Dari Tabel 4 dapat dilihat bahwa penggarapan format data telah menghasilkan format enam variabel data dimana masih ada satu variabel format data yang belum dibuatkan yakni Variabel Data Perlindungan Sosial. Format data ini tidak diselesaikan dengan pertimbangan banyak hal yang belum diketahui oleh tim pengabdi mengenai format data yang akan digarap, serta format data tersebut membutuhkan waktu yang lama untuk digarap berhubung format ini berhubungan dengan Dinas Sosial. Adapun keenam format variabel data yang sudah disiapkan sudah disosialisasikan kepada ibu- 
ibu kader Kampung KB Teratai yang berhubungan dengan pendampingan inputting data.

\section{Pendampingan Inputting Data}

Program ini merupakan keberlanjutan dari program pembuatan format variabel rumah data, dimana pendampingan dilakukan untuk memberikan pemahaman yang lebih dalam kepada pengurus Rumah Data Kependudukan dan Informasi Keluarga mengenai bagaimana inputting data secara digital setelah melakukan inputting data secara manual di tingkat RT hingga rekapitulasi RW. Agenda pendampingan ini ditunjukkan oleh Tabel 5.

Tabel 5. Jadwal Pendampingan Inputting Data

\begin{tabular}{|c|c|c|}
\hline Hari/Tangal & Lokasi & Materi \\
\hline \multirow{9}{*}{$\begin{array}{l}\text { Sabtu. } 19 \text { November } 2020 \\
\text { Selasa, } 01 \text { Desember } 2020\end{array}$} & Rumah Ibu Utami & Penjelasan mengenai format data yang \\
\hline & (Kader Kampung KB & diedarkan dan bagaimana cara \\
\hline & Teratai) & melakukan inputting data secara \\
\hline & & manual serta alur datanya bagaimana. \\
\hline & Gedung Serbaguna & Pendampingan cara inputting data \\
\hline & Kelurahan Kauman Kidul & menggunakan PC dan Microsoft Office \\
\hline & & Excel kepada perwakilan kader \\
\hline & & sekaligus melakukan copy soft file \\
\hline & & format data \\
\hline
\end{tabular}

Pendampingan ini diikuti oleh kader-kader Kampung KB Teratai dan sekaligus merupakan pengurus Rumah Data Kependudukan dan Informasi Keluarga Kauman Kidul yang dimana pendampingan ini disambut baik oleh Pak Lurah, Ketua Rumah Data dan Ibu-Ibu Kader. Pendampingan ini sangat membantu pengurus Rumah Data dalam melakukan inputting data sehingga selanjutnya data tidak hanya berbasis manual lagi namun memiliki back up data secara digital. Adapun dokumentasi pendampingan ditunjukkan pada Gambar 4.

\section{Kegiatan 19 November 2020}

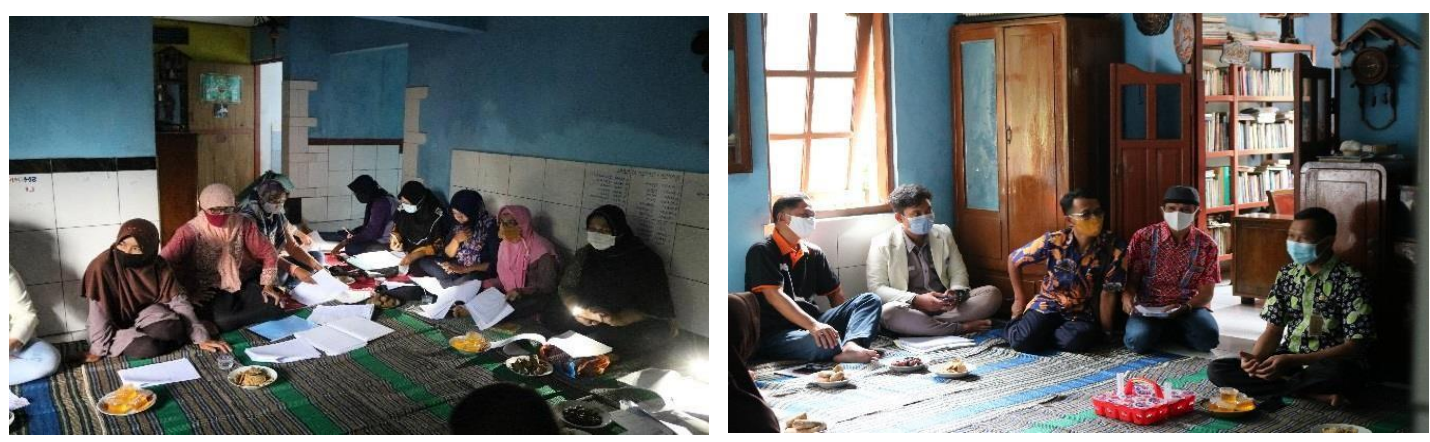



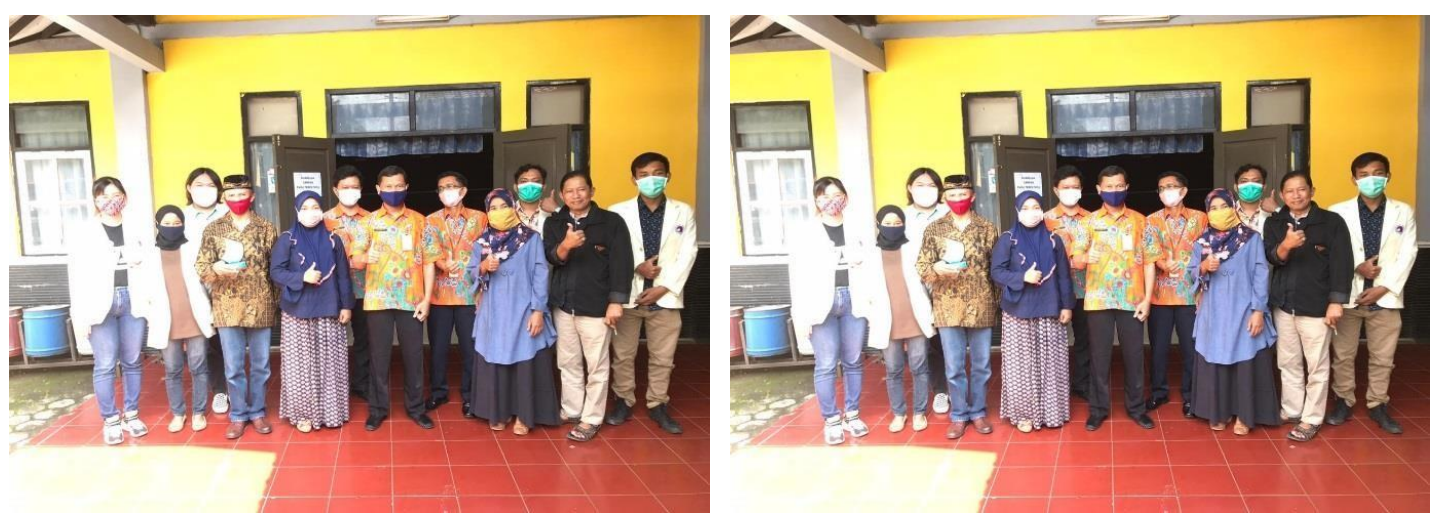

Gambar 4. Pendampingan Inputting Data

\section{Pembuatan Akun Media Sosial dan Video Profil Kampung KB}

Program ini merupakan program dukungan terhadap potensi alam dan potensi wisata yang ada di Kauman Kidul. Hal ini karena di era digital sekarang ini, promosi melalui media sosial sangatlah penting untuk menarik minat wisatawan datang ke Kauman Kidul sehingga dalam jangka panjang hal ini akan membawa kemajuan bagi kesejahteraan masyarakat Kauman Kidul. Oleh sebabnya, penggarapan akun media sosial Kampung KB Teratai sangat penting untuk dibuat. Selain menjadi media promosi, melalui akun ini pula pengurus Kampung KB Teratai dan Rumah Data Kependudukan dan Informasi Keluarga dapat mengunggah kegiatan Kampung KB Teratai agar dapat diketahui oleh BKKBN pusat sehingga Kampung KB Teratai dapat ditingkatkan pada level paripurna.

Pembuatan akun media sosial ini sudah dilakukan oleh tim pengabdi pada tanggal 23 Oktober 2020, dimana sejak tanggal tersebut sudah ada beberapa kegiatan yang di-posting. Adapun akun sosial media dan postingan-nya dapat dilihat pada Gambar 5: 


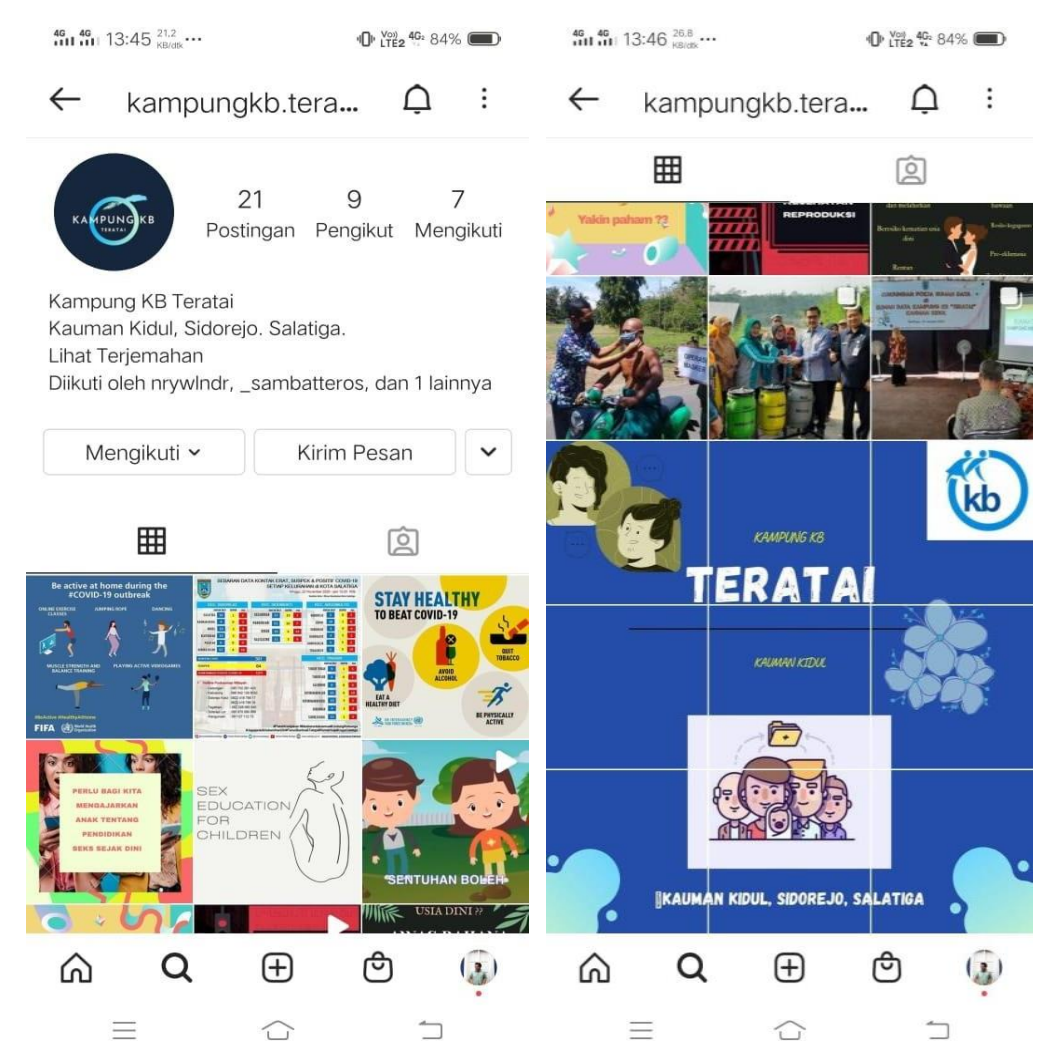

Gambar 5. Akun Sosial Media Kampung KB Teratai

Video Profil Kampung KB Teratai sendiri merupakan sebuah karya video yang berisi mengenai tampilan video ataupun gambar yang menceritakan tentang Kampung KB Teratai Kauman Kidul yang berisi mengenai sejarah berdirinya Kampung KB Teratai Kauman Kidul dan gambaran luas wilayah, potensi wilayah, fasilitas umum, program dari masing-masing pokja dan tak lupa mengenai data-data kependudukan yang ada di Rumah Data. Video profil ini sendiri melibatkan Kepala Kelurahan Kauman Kidul dan Kepala Rumah Data Kependudukan dan Informasi Keluarga yang menjelaskan mengenai kondisi wilayah Kauman Kidul dan Rumah Data itu sendiri. Adapun teknik pelaksanaan video profil dapat dilihat pada Tabel 6 berikut:

Tabel 6. Teknis Pelaksanaan Pembuatan Video Profil

\begin{tabular}{|c|c|c|c|}
\hline No & Tanggal & Tempat & Kegiatan \\
\hline 1 & 10 November 2020 & Rumah Data & $\begin{array}{c}\text { Pembuatan script dan narasi } \\
\text { voice over }(V O)\end{array}$ \\
\hline 2 & $\begin{array}{c}13-15 \\
\text { November } 2020\end{array}$ & $\begin{array}{l}\text { Wilayah Kauman } \\
\text { Kidul }\end{array}$ & Take Video \\
\hline 3 & 22 November 2020 & Kelurahan & Take Video Pak Lurah \\
\hline 4 & 24 November 2020 & Rumah Data & $\begin{array}{c}\text { Take Video Kepala Rumah } \\
\text { Data }\end{array}$ \\
\hline 5 & 25 November 2020 & Rumah Mahasiswa & Take VO \\
\hline 6 & 27 November 2020 & $\begin{array}{c}\text { Wilayah Kauman } \\
\text { Kidul }\end{array}$ & Take Video Stock Shoot \\
\hline
\end{tabular}


7

29 November $2020-30$

Rumah Mahasiswa

Editing Video

November 2020

Setelah video selesai di edit, maka video yang sudah jadi ditampilkan saat kegiatan pelepasan pada tanggal 01 Desember 2020 di gedung serbaguna Kelurahan Kauman Kidul. Video ini diharapkan nantinya dapat digunakan dalam memperkenalkan Kampung KB Teratai dalam berbagai kesempatan yang ada. Adapun video profil Kampung KB Teratai ini dapat diakses pad tautan berikut https://www.youtube.com/watch?v=XL_d-rxtRWM.

\section{SIMPULAN}

Kegiatan pengabdian dan pemberdayaan di Kampung KB Teratai Kelurahan Kauman Kidul pada dasarnya memberikan manfaat yang banyak bagi para pengurus Kampung KB Teratai dan pengurus Rumah Data Kependudukan dan Informasi Keluarga. Melalui penggarapan Rumah Data, format variabel data dan inputting data, para pengurus memiliki ruang untuk berkumpul dan melakukan verifikasi, analisis dan pengarsipan data. Selain itu pula masyarakat dipermudah dalam melakukan pencarian data dengan format yang sudah ada serta penginputan yang lebih teratur melalui penginputan digital, sehingga masalah data tercecer dan hilang dapat terhindari melalui penginputan data digital ini.

Melalui kehadiran Rumah Data di Kampung KB Teratai Kelurahan Kauman Kidul, masyarakat pada umumnya juga dipermudah untuk melihat secara garis besar demografi dan persebaran penduduk di Kelurahan Kauman Kidul, disamping itu Rumah Data ini dapat menjadi perantara antara pihak BKKBN dan Kelurahan dalam melakukan sensus penduduk sehingga masalah perbedaan data dapat diatasi, selain itu pula melalui Rumah Data ini pihak BKKBN dan Kelurahan dapat mengetahui permasalahan-permasalahan apa yang sedang terjadi di Kampung KB Teratai melalui papan permasalahan yang ada.

Selain itu pula, kehadiran Video Profil Kampung KB dan Akun Sosial Media juga memberikan dampak promosi bagi daerah Kauman Kidul, dimana promosi ini dapat memperkenalkan potensi wisata yang terdapat di Kauman Kidul baik potensi alam maupun wisata sejarah yang dimilikinya sehingga publik secara luas mengetahui potensi tersebut dan mengunjunginya, hal ini pun akan membawa dampak bagi perekonomian masyarakat di Kauman Kidul. Disamping itu, kehadiran pojok baca dalam Rumah Data dapat berguna untuk mengembangkan pengetahuan masyarakat Kauman Kidul terhadap berbagai hal, penyediaan prasarana ini sekaligus mendukung pencapaian pengembangan aspek pendidikan di Kauman Kidul.

Berbagai kegiatan pengabdian dan pemberdayaan yang dilakukan di Kampung KB Teratai Kelurahan Kauman Kidul pada intinya berusaha untuk menaikkan taraf Kampung KB Teratai ke taraf Kampung KB Paripurna yang dimana hal ini selaras dengan penghargaan yang diterima Kampung KB Teratai sebagai Kampung KB percontohan se-Salatiga (center of excellent). 


\section{DAFTAR PUSTAKA}

BKKBN. (2020). Lokakarya Mini Tingkat Kecamatan Kampung KB (pp. 1-15). Semarang: BKKBN.

BKKBN. (2017). Petunjuk Teknis Kampung KB, Direktorat Bina Lini Lapangan

BKKBN. (2017). Pedoman Pengelolaan Kampung KB. Jakarta : BKKBN

Badan Pusat Statistik (BPS). 2011. Hasil Sensus Penduduk 2010. Jakarta

https://kampungkb.bkkbn.go.id/postSlider/1231/73880

https://referensi.elsam.or.id/2014/10/uu-nomor-52-tahun-2009-tentang-

perkembangan-kependudukan-dan-pembangunan-keluarga/

https://www.youtube.com/watch?v=XL_d-rxtRWM.

Lembaran Negara. 2009/ No. 161, TLN NO. 5080, LL SETNEG : 36 HLM, Jakarta

Purnomo, Daru (2020). Remaja, Perkawinan Usia Anak, dan Pengembangan Kampung KB. Salatiga: Satya Wacana University Press.

Purnomo, Daru (2021). Aspek Sosio Politik Menuju Indonesia Tumbuh Seimbang (Materi yang diseminarkan Dalam Forum Webinar yang diselenggarakan oleh PSH-UKSW dahn LIPI pada 16 Pebruari 2021)

Ulum, Chazienul M dan Niken Lastiti VA (2020). Community Empowerment: Teori dan Praktek Pemberdayaan Komunitas. Surabaya: Universitas Brawijaya Press. 